MÉSZÁROS Ádám

\title{
A VÁLSÁG UTÁNI AUTÓIPARI BESZÁLLÍTÓI RENDSZEREK ÉS A HAZAI BESZÁLLÍTÓK LEHETŐSÉGEI
}

A gazdasági válság az autóipart különösen mélyen érintette. Nem csupán a nagymértékú visszaesés gyakorol hatást a beszállítókra, a beszállítói rendszer mélyebb átalakulásának is szemtanúi vagyunk. Várhatóan tovább fog növekedni az ágazat koncentrációja, mélyülni fognak a beszállítói kapcsolatok, nagyobb lesz a különbözó́ együttmúködések szerepe, illetve elôtérbe kerülnek a környezetvédelmi szempontok, és a várhatóan ismét magassá váló energiaárak miatt bekövetkezik egy jelentôs technológiai váltás. Mindezek változásokat generálnak a ma alapvetốen toyotista elvek szerint múködő beszállítói rendszerekben. Kulcsfontosságú az a kérdés, hogy a magyar beszállítók meg tudják-e ôrizni pozícióikat a megváltozott környezetben. A Suzuki beszállítóit vizsgáló, mélyinterjús kutatáson alapuló klaszterelemzés a magyarországi beszállítók négy csoportját különítette el. A „hazai kisvállalkozások”, a „heterogén hazai középmezôny”, a „külföldi nagyvállalatok” és a „,megfiatalodott dinoszauruszok” csoportja várhatóan eltéró módon fog beilleszkedni a megváltozott értékláncba, ahol elsốsorban a vállalati méret, a technológiai együttmúködésben való részvétel képessége válik egyre fontosabb versenyelônnyé.

Kulcsszavak: válság, autóipar, beszállítói hálózatok

A közvetlen külföldi beruházások és a beszállítói kapcsolatok ágazati, makro- és mikroszintú elemzése a külföldi szakirodalom slágertémája (lásd például Dyer, 1996; Aller, 1999; Hirschman, 2000; Lipsey, 2002; UNCTAD 2001). Hazánkban a problémakör - párhuzamosan a külföldi tókére erőteljesen támaszkodó modernizációs stratégia megvalósulásával - az 1990-es évek második felétól vált a közgazdasági diskurzus fontos elemévé, a beszállítókról szóló empirikus kutatások jelentős részben ez után készültek (ezek összefoglalóit lásd többek között: Árva, 1997; Sass-Szanyi, 2004; Mészáros, 2004; Sass et al., 2006).

A hazai beszállítókról szóló tucatnyi kutatás közül azonban csak néhány olyan volt, amely a beszállítókat tipizálta volna, amely az igen heterogén beszállítók között csoportokat különített volna el. Sốt, a külföldi vállalatok importhányadát, a hazai beszállítók szerepét, az integráltságot, a külföldi vállalatok elvárásait és a hazai beszállítók versenyképességét vizsgáló kutatások egy része kezdetben nem különböztette meg a magyar tulajdonú vállalatokat a hazánkban múködố vegyes tu- lajdonban levô, illetve külföldi vállalatoktól (Farkas, 2001). Másrészt a kutatások egyáltalán nem vizsgálták meg az elsốvonalbeli beszállítók beszállítóit, vagyis az értékláncban hátrább levố vállalatokat sem (Mészáros, 2009). Empirikus kutatásom többek közt azt tûzte ki célul, hogy az elsố- és másodvonalbeli beszállítók között elkülönítse a hazai beszállitók különbözó csoportjait.

A beszállítókat tipizáló, különböző csoportokba soroló tanulmányok közül Árva és Diczházy 1990-es évek végére vonatkozó kutatása emelhető ki, mely szerint a hazai tulajdonú beszállítói cégeknek három fó csoportja volt megkülönböztethető (Árva - Diczházy, 1998). Az elsô csoportba az egykori állami, privatizált nagyvállalatok tartoztak, amelyek elvesztették piacaikat, pénzügyileg leépültek, ugyanakkor infrastruktúrájuk, munkaerejük java megmaradt. Itt a külföldi partner alapvetően bérmunka jellegú kooperációt valósít meg, az anyagokat, alkatrészeket a partner adja, a piacot is biztosítja, átadhat technológiát is. A második jellegzetes csoportba olyan középvállalatok tartoznak, amelyeknek múltjuk miatt megfelelő referenciájuk van, és így 
a legjobb lehetőségük van kedvező beszállítói pozíciók szerzésére. A harmadik, igen hátrányos helyzetú csoport olyan magánvállalkozóké, amelyek megfelelő referencia hiányában még viszonylagos rugalmasságuk és gyorsaságuk ellenére sem tudnak jó pozíciókhoz jutni.

Egy másik hazai kutatás (UK Know How Fund, é. n.) a hazai vállalatokat SWOT-analízis segítségével három csoportba osztotta, melyek rendezóelvei a piaci pozíció és a piaci kilátások voltak. Az elsô, gyenge piaci pozícióban levố csoportba azok a kis- és középvállalatok tartoznak, amelyek beszállítói tradíció nélkül, alacsony technológiai színvonallal, komolyabb menedzsmentismeretek, illetve -kapcsolatok nélkül próbálnak belépni a piacra. A közepes piaci erővel bíró vállalatoknak van beszállítói tapasztalata, felkészülttek, és viszonylag jók a kapcsolataik. Az erôs piaci pozíciójú csoport cégei komoly beszállítói tradíciókkal rendelkeznek, magas technológiai színvonalat képviselnek, kapcsolataik stabilak. Az idézett kutatás a lehetséges felvevoópiacok osztályozását is elvégezte: nagy piacnak tekinti a multinacionális összeszerelő vállalatokat, illetve közvetlen beszállítóikat. Ez a piac nem csupán nagy, hanem viszonylag zárt is, mivel a szereplók kapcsolatai kialakultnak tekinthetók, az elvárások pedig igen magasak. A közepes piacok kevésbé zártak, a közvetlen beszállítók, a magyar összeszerelók, illetve a magyar integrátorok találhatók ebben a csoportban. Az elvárások itt is magasak, azonban itt már könnyebb beszállítóvá válni. A kis piacok (például hazai részegységgyártók) közepes elvárásaikkal közepesen nyitottak, azonban - méretük miatt - csak lokális, regionális szinten jelenthetnek húzóerốt a kis- és közepes magyar vállalatoknak.

Mint látni fogjuk, az autóipari átalakulások egyik hatása az, hogy a jelenleg viszonylag zárt piacok némileg nyitottá, majd az új kapcsolatok megszilárdulásával ismét zárttá válnak. Másik hatás, hogy megváltozik a piac mérete. Nem csupán arról van szó, hogy a válság nagymértékben szúkíti a piacot, és elóbb-utóbb megindul egy újabb fellendülés, hanem arról is, hogy $a$ vállalati koncentráció és a készüló modellek szélesebb vagy szúkebb skálája határozza majd meg a vállalatok számára releváns piac méretét. Az idézett kutatás a kis- és közepes vállalatok lehetőségeit a lehetőségek mátrixában foglalta össze az 1. táblázatban.

Ezek a megállapítások nemcsak azért fontosak, mert a beszállítók csoportjai és azok jellegzetességei ma is relevánsak lehetnek, hanem azért is, mert a piac (pontosabban a partnerek) elvárásainak rendszerbe emelésével rávilágítanak arra, hogy a beszállítók erôsségei csak bizonyos környezetben, bizonyos partneri elvárások mellett használhatók ki, s más piacon az elvárások is módosulnak, más vállalatok lehetnek csak sikeresek.
1. táblázat

Kis- és közepes vállalatok beszállítóvá válásának lehetôségei

\begin{tabular}{|c|c|c|c|}
\hline & \multicolumn{3}{|c|}{ A beszálítói piac mérete } \\
\hline Kkv-k felkészültsége & nagy & közepes & kicsi \\
\hline gyenge & gyenge & gyenge & közepes \\
\hline közepes & gyenge & közepes & kedvezó \\
\hline erós & közepes & kedvezó & kedvezó \\
\hline
\end{tabular}

Forrás: UK Know-how Fund: Összefoglaló jelentés és javaslatok megfogalmazása a kkv-szektor lehetốségeinek fejlesztésére.

A fenti megállapítások egybecsengenek Sass Magdolna és Szanyi Miklós (2004) összegzésével. Ezek szerint a helyi beszállítások szintjét a következő tényezók határozzák meg: a beruházás típusa (zöldmezôs beruházás, privatizált vállalat, egyesüléssel, öszszeolvadással létrejött vállalat), a szektorális jelleg, az exportorientáltság szintje, a beruházó országa, a hazai és a külföldi vállalati szektor közötti különbség, a potenciális hazai beszállítások minősége és mennyisége, a külföldi vállalatok globális stratégiája, a hazai leányvállalatnak a multinacionális vállalat termelési hálózatában elfoglalt helye.

Tanulmányom célja pedig épp annak meghatározása, hogy a magyarországi beszállitók különbözó csoportjai milyen helyet foglalhatnak el a válság hatására megváltozó termelési láncban.

\section{A beszállítók csoportjai}

Az előző alfejezetben idézett kutatásoknál az általam végzett felmérés alapján létrehozott vállalatcsoportok alkalmasabbak arra, hogy válság utáni rendszerben elfoglalt helyüket megpróbáljam meghatározni. Ennek oka nemcsak az, hogy kutatásom jóval frissebb az idézetteknél, hanem az is, hogy a kutatás célja nem csupán az egyes beszállítói csoportok elkülönítése volt, hanem az is, hogy a beszállítói hálózat jellemzóit, valamint a vállalatok abban elfoglalt helyét meghatározza.

Az empirikus kutatás alapját a Suzukit, illetve a Suzuki első- és másodvonalbeli beszállítóit vizsgáló mélyinterjúim jelentették, melyek keretében 30 vállalatvezetốt kerestem fel. Az interjúk a válság elôtt (zömében 2007-ben) készültek, az eredményeknek azonban a válság, pontosabban a válság után kialakuló új rendszer különös jelentőséget ad. A 29 vállalatból álló minta elemzéséhez, a vállalati csoportok kialakításához a klaszteranalízis módszerét használtam. ${ }^{1}$ A statisztikai elemzés módszertani részleteitôl e helyütt eltekintek, csupán annyit jegyeznék meg, hogy a klaszteranalízis 
során az árbevétel, az alkalmazotti létszám és a jegyzett tốke nagysága, a vállalatok kora és a külföldi tôke aránya jelentették a bevont változókat. Az így kapott négy klaszter a Magyarországon múködó Suzuki-beszállitók négy jól megkülönböztethetó csoportját jelenti.

\section{Hazai kisvállalkozások}

Az elsô (11 vállalatot tartalmazó) klaszterben döntôen magyar tulajdonú, nagyon kis részben vegyes tulajdonú vállalatok találhatók, döntő többségük az 1990-es, illetve 1980-as években alakult, egy részük tipikus családi vállalkozásként. Tulajdonjogilag függetlenek, nem állnak anyavállalatok irányítása alatt. A vállalatok mintegy fele nem elsố vonalbeli beszállító, csak a Suzuki partnereivel, beszállítóival állnak kapcsolatban, így a vertikális láncban a második sorban helyezkednek el. A gyártott termék és a tevékenységtípus szerint ez a klaszter igen heterogén, hiszen találhatunk csupán forgalmazással foglalkozó vállalatot éppúgy, mint alacsony hozzáadott-értékú termékek gyártásával, fröccsöntéssel, préselt alkatrészek gyártásával foglalkozót, de akad köztük szerszámgyártásra, prototípusgyártásra, egyedi célgépek gyártására, múszaki fejlesztésre és tanácsadásra szakosodott vállalat is. Tehát korántsem állítható, hogy az ebbe a klaszterbe tartozó cégek csak alacsony hozzáadott-értékú, bérmunkaszerú tevékenységeket végeznének. Erre utal, hogy néhányuk esetében a vállalat megalakításának oka kifejezetten a szaktudás, mérnöki tudás hasznosítása volt. Kis részüknél haladja csak meg a Suzukinak történő közvetlen és közvetett beszállítások aránya az 50\%-ot, az egyoldalú függés csak a csoport egy részére jellemző. Kis- és közepes vállalkozások, az árbevétel egy cég esetében sem haladja meg az egymilliárd Ft-ot, alkalmazotti létszámuk nem nagyobb 80 fónél.

\section{A heterogén hazai középmezóny}

A második (hat vállalatot tartalmazó) klaszter cégei (egy vegyes vállalat kivételével) tisztán hazai tulajdonban vannak. Ezek egy része egykori állami nagyvállalat volt, más részük az 1990-es években jött létre hazai kisvállalkozásként, ezután dinamikusan növekedett. Elóbbi csoport jó része viszonylag sikeresen átalakult egykori állami vállalat, illetve annak része, utóbbi csoport pedig egyértelmúen sikeres, eredetileg is magántulajdonú hazai vállalkozás. Mindkét csoport a duálisnak mondott (Hamar, 2001; Hamar - Nagy, 2001) hazai gazdaság magyar tulajdonú középvállalata, némiképp ellentmondva a dualitás tételének. Tevékenységét tekintve a csoport igen heterogén. A cégek nagy részére nem jellemző, hogy túl nagy lenne a Suzuki aránya az árbevételben, az egyoldalú függőség ebben a csoport- ban inkább kivételes. Árbevételük többségében kétmilliárd Ft körüli, illetve feletti, egy részük nagyvállalat, döntő többségük nagyobb középvállalat (250-tól nem sokkal elmaradó foglalkoztatotti létszámmal), viszonylag magas a vállalatok jegyzett tókéje, sok esetben meghaladja a százmillió Ft-ot.

\section{Külföldi nagyvállalatok}

A harmadik klaszter hét tagja egy (többségében külföldi tulajdonban levô) vállalat kivételével kizárólagos külföldi tulajdonban levő, zöldmezôs beruházással vagy privatizációval az 1990-es évek elején létrejövő, külföldi anyacéggel rendelkező vállalat. Tevékenységük heterogén, magas technológiai színvonalat képviselő, a Suzuki szempontjából stratégiai terméket éppúgy találunk, mint fröccsöntést vagy kereskedelmet. Többségük elsố vonalbeli beszállító, közvetlenül kapcsolódnak a Suzukihoz, ók helyezkednek el a beszállítói piramis tetején. A vállalatok többségének éves árbevétele kétmilliárd Ft felett van, van közöttük több 250 fő fölötti nagyvállalat, egy kivételével száznál több alkalmazottjuk van, s többségük a válság előtt a vállalat dinamikus növekedéséról számolt be.

\section{Megfiatalodott dinoszauruszok ${ }^{2}$}

A klaszteranalízis által külön csoportba sorolt négy nagyvállalat méretét (árbevétel, alkalmazotti létszám, jegyzett tớke) tekintve a minta legnagyobb cégei között van. Közülük két vállalat igen nagy múltra tekint viszsza, míg a másik kettó megalakulása az 1960-as évek iparosítási hullámának eredménye. Utóbbiak tisztán magyar tulajdonban levoók, az elóbbiek közül egyik vegyesvállalat, másik tisztán külföldi tulajdonban van. A négyból három vállalatot a Suzuki keresett meg, s kérte fel ôket beszállítónak még 1992-ben. Látszik, hogy a Suzuki bízott a hagyományos nagyvállalati körben, ez az 1990-es évek elejének épp csak formálódó hazai kis- és középvállalati szektorát tekintve érthető. A Suzuki mindegyik vállalat fontos vevóje, de csak az egyik esetben haladja meg a részesedés az 50\%-ot. A több lábon állás és a kisebb kiszolgáltatottság feltétlenül nagy elônyt jelent. Közülük két vállalat is volt már az Év Beszállítója.

\section{A beszállítók pozíciója a válság elôtt}

A versenytársakat és a versenyhelyzetet a vizsgált vállalatok igen eltéróen ítélték meg. A szolgáltatással, speciális termékek gyártásával foglalkozók közül több is beszámolt arról, hogy alig akad versenytársa, ennek oka, hogy a vállalat igen speciális terméket gyárt, illetve hogy a sikeres kapcsolat kialakításában sokat 
számít a földrajzi távolság. A nagyobb értékú terméket gyártó vállalatok esetében jellemzó volt a globális verseny, míg a múanyagipari és fémipari cégek nagy része hazai, illetve regionális versenytársakról számolt be, nemritkán a mintában szereplő más vállalatok némelyikét konkrétan is megnevezve. Ez utóbbi kategóriákban mind a globális, mind a regionális, mind a hazai versenyt erősnek és növekvőnek nevezték.

A verseny a vizsgált vállalatok mintegy fele szerint árverseny. Kell egy adott minôséget nyújtani, de a szintet teljesítók között az ár az egyetlen kritérium. A minőséget, a pontosságot viszonylag kevés vállalat említette, ezek kis része a múanyagipari, de többségük speciális terméket gyárt, illetve szolgáltatást nyújt. Néhány vállalat megemlítette az informális kapcsolatok fontosságát is.

A beszállítók egy része kizárólagosan felelős egy adott termékért. Véleményem szerint egy ilyen helyzetben mindkét fél számára fontos a megbízhatóság és a hosszú távú gondolkodás. S mivel akár egy termék hiánya is képes zavarokat okozni a termelésben, a megrendelô számára a partner megtartása kulcsfontosságú. Ezt igazolja a ritkán ugyan, de előforduló minőségi hibák kezelése is: ezek nem feltétlenül jártak a kapcsolatok megszakadásával.

Összességében úgy túnik, a vállalatok nagy része a válságot megelózó idốszakban stabilan órizte pozícióját, a Suzuki állandó partnere volt. A versenyelónyt firtató nyitott kérdésre azonban rendkívül sokféle, ám a vállalatokról kialakult képet nagyrészt alátámasztó választ kaptam, ezek a következók voltak.

A külföldi tulajdonú cégek leányvállalatai közül több a hozzáértést, a tốkeerôt és a méretgazdaságosságot, az anyacég globális kapcsolatait említette versenyelőnyként, egy-egy vállalat a márkanevet, a terméktervezésben megmutatkozó elônyeit, az értéknövelt szolgáltatás nyújtásának képességét, a K+F előnyöket hozta fel.

A magyar tulajdonú kis- és közepes, újonnan alakult vállalkozások (tehát a heterogén középmezőny és a hazai kisvállalkozások) közül többen említették a kis méretet, a rugalmasságot, a versenyképes árat, egy-egy cég a központi vezetés előnyeit, a hozzáértést, a szellemi tőkét, a kis piaci szegmens megcélzását, az egyedülálló technológia alkalmazását, a kapcsolatrendszert, a megbízhatóságot, a minőséget, a tốkeeroot, a növekedést.

A megfiatalodott dinoszauruszok mindegyike a tapasztalatot, az iparágba történó korai belépést és a méretnagyságot, kisebb arányban a sikeres átalakulást, a japán minták átvételét, az alacsony vidéki munkabéreket tartotta fontosnak.

A legfontosabb kérdés az, hogy ezeket a versenyelónyöket, illetve a fent már ismertetett erósségeket a vállalatok az új környezetben, az új elvárásokkal szembesülve hogyan lesznek képesek kihasználni.

A megkérdezett vállalatok már a válság előtt is számos olyan veszélyt, illetve gyengeséget említettek, amelyek a helyzetüket negatívan befolyásolhatják. Az egyik legnagyobb veszélyt a fokozódó árverseny jelenti, amelynek oka nemcsak a szaporodó versenytársakban keresendó, hanem abban is, hogy a cégek az egyik vállalatvezető szavaival élve „kettős prés” alá kerültek. Ez egyrészt a növekvô alapanyagáraknak, másrészt a megrendelók kemény és versenyeztetố árpolitikájának volt köszönhetố - a válságról szóló amerikai elemzések kiemelik, hogy ez a válság hatására sem enyhült (US Department of Commerce, 2009).

Súlyos problémát jelent még ezenkívül több cég esetében a kiszolgáltatottság, a legfontosabb partner nagy súlya az árbevételben. Ezen már a válság előtt is több cég változtatni szeretett volna, de ez épp a kapacitáskorlát és a tókehiány (mint a növekedést és a termelés diverzifikációját akadályozó tényezók) miatt nem könnyú. A konjunktúraérzékeny, a többi szektornál, illetve a GDP-nél volatilisebb autóipart (OECD, 2009) a válság a többi iparágnál is érzékenyebben érintette (IMF, 2009). Az egy lábon állás, a kiszolgáltatottság jelentős hátránnyá vált, a kereslet visszaesése miatti termeléscsökkenés rendkívül gyorsan végigfutott a vertikumon. A válság hatásai azonban túlmutatnak egy erôteljes ciklikus visszaesésen, és hosszabb távon is meghatározhatják a beszállítói rendszer jövőjét.

\section{Az autóipari beszállítói hálózatok átalakulása a válság elốtt}

Az autógyártás - szervezeti, termelésszervezési szempontból - igen innovatív iparág. Az 1900-as évek legelején az autóipar kisipari termelési rendszere a részegységeket gyártó független vállalkozókon, illetve a termelés folyamatát technológiai, szervezési szempontból átfogni képtelen autógyártókon alapult. Majd a fordizmus egy technológiai rendszerbe illesztette a teljes gyártási folyamatot. Ennek fontos eszköze a részegységek szabványosítása, standardizálása volt: a kisipari termelési rendszer pontatlan, sok esetben utólagos megmunkálást igénylő alkatrészeit felváltották a standard, egymáshoz pontosan illeszthetô, egyszerúen összeszerelhetô alkatrészek. A beszállítók nem vettek részt a termékek tervezésében, a tervezés területén az együttmúködés ismeretlen volt. A kicsi, könnyen lecserélhetố beszállítók egymással áralapú versenyt folytattak (Turnbull - Oliver - Wilkinson, 1992; Hudson, 1994; Streeck, 1998).

A toyotizmus alapjaiban változtatta meg a beszállítói rendszert: a rugalmasan helyettesíthető, rövid 
távra alkalmazott partnerek helyett a japán, illetve a toyotizmus elveit átvevô autógyárak megpróbáltak hosszabb távú kapcsolatokat kialakítani beszállítóikkal. A közvetlen beszállítók számát radikálisan csökkentették, a nagyobb, megbízható partnereket részesítették előnyben. Az így kialakuló kapcsolatok mindkét fél részérôl növelték a függôséget, ezért a partnerek kiválasztása elődleges fontosságúvá vált (Turnbull Oliver - Wilkinson, 1992).

A kapcsolatok megszilárdultak, egyre szorosabbá váltak, a partnervállalatok már nem csupán alvállalkozók, kisebb egységek beszállítói, hanem egyre komplexebb részegységek gyártói lettek, amelyeket az autógyártók ösztönöztek a növekedésben, stabil és növekvố volumenú megrendelésekkel láttak el. A tömegtermelést felváltó tömeges személyre szabás a beszállítók részéról is nagyobb rugalmasságot, magasabb fokú technológiai együttmúködést kívánt meg. A vertikális láncban így nagy különbség alakul ki az autógyár stratégiai, technológiai partnereinek tekintett elsố vonalbeli (közvetlen) beszállítók, illetve ezek beszállítói, a másodvonalbeli beszállítók, illetve az ôket kiszolgáló harmadik stb. vonalbeli beszállítók között.

Az elsố vonalbeli beszállítók egyre inkább stratégiai partnerré váltak, amelyek sok esetben részt vettek a termékek tervezésében is. Ők már nem alkatrészeket, hanem részegységeket, teljes rendszereket szállítottak be. A toyotizmus rendszerében az elsố vonalbeli beszállítók integrátorként múkködnek: egy-egy vállalat több tucat alvállalkozóból, beszállítóból álló hálózatot fog össze: a vertikális láncot ő irányítja. Az alsóbb szinteken lehetôvé válik a specializáció, egy-egy kisebb vállalat csupán meghatározott, egyszerú múveletekkel foglalkozik, igen szabályozott keretek között (Futó - Hurton, 1997, Hudson, 1994, Fujita - Hill, 1995; Humphrey - Memedovic, 2003).

A fenti folyamatok ellenére sem állítható azonban, hogy az autóipari beszállítói rendszerek teljes egészében toyotistákká váltak volna, inkább egyfajta konvergencia volt megfigyelhetô az európai és amerikai, fordizmus jegyeit még jobban magukon viselő struktúrák és a klasszikus toyotizmus beszállítói rendszere között (Kim - Michell, 1999), a vállalatok rendszerei ugyanakkor továbbra is különböznek egymástól (Bensaou - Venkatraman, 1995).

Az autóipar az ezt megelôzó válságokra is strukturális átalakulással reagált (Somai, 2009), s most is $a z a$ fó kérdés, milyen változások mennek végbe, pontosabban, hogy a válság alatt, illetve a válság után kialakuló új rendszerben mi lesz a szerepe az beszállitóknak, folytatódik-e a toyotista struktúrák térhódítása?

\section{A beszállítói hálózatok átalakulása}

Mivel a magyarországi (és térségbeli) autó-összeszerelók szinte mindegyike, illetve a beszállítók jelentős része is multinacionális vállalatcsoport tagja, így a nemzetközi trendek a magyar piacon is érezhetők, illetve érezhetóek lesznek. Az, hogy mindezek milyen mértékben, illetve sebességgel érvényesülnek, természetesen függ többek között a vállalatcsoport centralizációjának mértékétől, a döntéshozatali mechanizmusoktól, a vállalat stratégiájától, valamint a hazai vállalati környezettól is.

A beszállítói rendszerek szempontjából véleményem szerint a vállalati méret, illetve a koncentráció növekedése, a kapcsolatok mélyülése, valamint a (környezetvédelmi szempontok és a jövő́beli magas energiaárak miatt bekövetkezó) technológiai váltás lehetnek azok a tényezók, amelyek a beszállitoi hálózatok múködését hosszabb távon is befolyásolják. Természetesen 2010 legelején végleges következtetéseket nem lehet még levonni, a legfrissebb ágazati adatokból a fontosabb trendek azonban már kirajzolódnak.

Az egyik legfontosabb kérdés, hogy a válság milyen hatást gyakorol a koncentrációra, illetve a felvásárlások és összeolvadások dinamikájára. Az ágazatra már a válság előtt is növekvő koncentráció volt jellemzô. Az autóipari (összeszerelóket és alkatrészgyártókat érintő) felvásárlások lendülete a válság hatására mind értékben, mind a tranzakciók számát tekintve megtört, azonban világszinten még 2008-ban is meghaladta a 31 milliárd dollárt a felvásárlások és összeolvadások összértéke, számuk pedig 2007-hez képest alig csökkent (604-rôl 549-re). (PWC, 2009a). 2009-es összesített adatok még nem állnak rendelkezésre, azonban valószínúsíthetjük, hogy a felvásárlások lendülete (már csak a csődök és az ezzel összefüggó felvásárlások miatt sem) tört meg teljes mértékben, ez pedig a piaci koncentráció további növekedését okozhatja. További érdekes jelenség, hogy mivel az autóipari beszállítók az autógyártók szempontjából kulcsfontosságúak, és a válság hatására elóbbiek stabil múködése veszélybe került, az autógyártók különböző eszközökkel maguk is ösztönzik beszállítóik koncentrációját. Átviszik szerszámaikat egy másik, stabilabb helyzetben levố beszállítóhoz, ráveszik beszállítóikat, hogy vásárolják fel a gyengébbeket, esetleg saját maguk vásárolják fel ôket (Somai, 2009). Hosszabb távon a válság tehát csak mérsékelten törte meg a koncentráció növekedésének lendületét, vagyis az várhatóan a válság alatt és annak elmúltával növekedni fog.

Másrészról a vállalatok közötti (tulajdoni összefonódással nem összefüggố) együttmúködések szerepe is növekszik. Ahogy Sergio Marchionne, a Chryslerrel 2009 elején megállapodást kötő Fiat vezetôje fogalma- 
zott: „Ebben az iparágban a függetlenség többé már nem fenntartható. Többé már nem lehetséges, hogy saját magunk gyártsuk az autókat”. (Marchionne, 2009) Az USA-ban a három autóipari óriás (Detroit 3) is mélyebb együttmúködésre törekszik, különösen a kutatás-fejlesztés, a design, a termelés területén (US Department of Commerce, 2009). Az iparági elemzések azt mutatják, hogy valószínúleg a beszállítói ipar is követni fogja a stratégiai szövetségek, technológiai és más együttmúködések irányába mutató trendeket (PWC, 2009b).

Rendkívül fontosak a beszállítói hálózatokat is nagymértékben érintő technológiai változások. A megfelelő technológia birtoklása, illetve a technológiai váltás képessége a dinamikusan változó környezetben versenyelönnyé válhat. A szigorodó környezetvédelmi előírások (a károsanyag-kibocsátási szintek csökkentése), valamint a válság elmúltával valószínúleg magassá váló olajárak miatti energiatakarékossági kényszer technológiai váltást kényszerít majd ki (Deloitte, 2009; PWC, 2009b). ${ }^{3}$

Egy olyan piacon, ahol a felvásárlások és összeolvadások, valamint a válság hatására bekövetkezô csôdök nagymértékben megváltoztatták a piac strukturális jellemzőit, a technológiai váltás kényszere további változásokat indíthat el. Jó példa erre, hogy 2009 végén a Suzuki és a Volkswagen olyan együttmúködési megállapodást írt alá, melynek célja energiatakarékos és kis szén-dioxid-kibocsátású autók piacra dobása - ráadásul a tervek szerint a Volkswagen valószínúleg megvásárolja a Suzuki részvényeinek 19,9\%-át (Suzuki, 2009).

A technológiai váltás szükségessége, az új modellek piacra dobása tehát megnöveli az autógyártók és a beszállitók közötti együttmúködés jelentoóségét. Az új technológiák és eljárások forrásai lehetnek ezentúl olyan innovatív beszállító vállalatok is, amelyekkel az autógyártó magasabb szintű együttmúködést alakít ki (természetesen nem zárható ki azok felvásárlása sem).

A beszállítók úgy próbálják megórizni pozícióikat, hogy újabb és újabb feladatköröket vállalnak át, legyen szó teljes modulok gyártásáról, vagy épp termékfejlesztésról. Azok a vállalatok, amelyek ezt nem teszik meg, egyre nagyobb versenynek vannak kitéve mind a versenytársak számát, mind az árakat tekintve. Az együttmúködés magasabb foka hatást gyakorol a vállalatok közötti földrajzi távolságra is: ez a térbeli koncentrációt növelő tényezô (US Department of Commerce, 2009). Ezzel párhuzamosan természetesen a méretgazdaságosság fontos versenyelőny lesz a jövoóben is.

Mindezek a trendek azt jelentik, hogy egyre koncentráltabb piacon, egyre nagyobb beszállítók alakítanak ki mélyebb együttmúködéseket az egymással is egyre jobban együttmúködó autógyártókkal.

\section{Lehetôségek és veszélyek: a hazai beszállítói csoportok további differenciálódása?}

A válságot túlélő, s néhány éven belül megnövekedett kereslettel (az elôrejelzéseket és szcenáriókat lásd például Harvey, 2009; PWC, 2009b) szembesülő beszállítóknak a fent elemzett új környezetben kell majd helytállniuk. Azok a jelenlegi autóipari beszállítók, amelyek tókeerốsebbek, alkalmasak technológiai együttmúködésre, valószínúleg sikeresen tudnak részt venni az újabb modellek részegységeinek beszállításáért folyó, várhatóan igen nagy versenyben. Számukra az új rendszer hatalmas lehetóségeket jelent majd. A külföldi nagyvállalatok sorsa nagyrészt hazai anyacégeik kezében lesz, önmagában nehéz lenne a leányvállalatok jelenlegi helyzetéból következtetéseket levonni, ceteris paribus (fenti erósségeiket tekintve) azonban ez a csoport az átalakulás nyertesévé válhat.

A megfiatalodott dinoszauruszok csoportja, valamint a nagyobb, tókeerósebb, fejlettebb technológiával rendelkezó heterogén hazai középmezóny nevú klaszter tagjai szintén alkalmasak lehetnek arra, hogy a megváltozott környezetben, az új elvárások mellett is beszállítók maradjanak. Ennek oka, hogy technológiájukat, tapasztalatukat, méretüket várhatóan ki tudják majd használni az új környezetben is.

Azok a vállalatok azonban, amelyek nem tudnak megfelelni az új technológiai követelményeknek, illetve árban nem tudnak versenyezni az egyre koncentráltabbá és nemzetközibbé váló piacon, ki fognak esni az elsố vonalbeli beszállítók közül. Ez a veszély a hazai kisvállalkozásokat és a heterogén hazai középmezóny kisebb, alacsonyabb technológiai színvonalat képviseló tagjait fenyegeti. Azok a vállalatok tehát, amelyek nem képesek mélyebb technológiai együttmúködésre, amelyek méretük révén nem tudnak majd megfelelni a növekvő mennyiségi igényeknek, ki fognak szorulni a piacról. A heterogén hazai középmezőny tagjai tehát differenciálódhatnak: azok a vállalatok, ahol a szaktudás volt eddig is a versenyelóny, képesek lehetnek az új technológiai kihívásokhoz alkalmazkodni, s ha nem jelent számukra hátrányt a kapacitáskorlát, talán helyt tudnak állni az új környezetben is.

A hazai kisvállalkozások csoportjára leselkedő legnagyobb veszély a piac növekvó koncentrációja, hiszen ók szembesülnek leginkább a kapacitáskorláttal, s egyre nagyobb cégekkel kell majd versenyezniük, valamint egyre nagyobb sorozatnagyságot igénylő vállalatok megrendeléseit kell majd teljesíteniük. Természetesen vannak tevékenységek (például prototípusgyártás, mérnöki tanácsadás), amelyek egyedi jellegüknél fogva kedvezhetnek a kis, rugalmas vállalatoknak. 
A lezajló technológiai váltás, az új modellek megjelenése mindenképpen fel fogja borítani a kialakult struktúrákat, új beszállitókat von majd be, régiek esnek ki a versenyból. Az autóipari átalakulások egyik hatása éppen az, hogy a jelenleg viszonylag zárt piacok (Csonka, 2009) némileg nyitottá, majd az új kapcsolatok megszilárdulásával ismét zárttá válnak. Mivel az autóipari beszállítói szerződések hosszú távra (akár 7-10 évre, egy-egy modell gyártásának időtartamára) szólnak, a már kialakult, konszolidálódott struktúrába kívülról belépni igen nehéz lesz: szúküilni fog az esetlegesen piacra lépó magyar kis- és közepes vállalatok lehetôsége arra, hogy az elsố beszállítói vonalba bekapcsolódjanak. Épp ezért lehet sorsdöntő az elkövetkezó néhány év a hazai vállalatok számára.

Ebben az esetben az újonnan belépó, illetve az első vonalból kiesố vállalatok (zömében a hazai kisvállalkozások és a heterogén hazai középmezóny csoportjának tagjai) számára a másodvonalbeli beszállítás jelenthet lehetőséget. Hogy mekkora ez a lehetőség, már részben technológiai kérdés: függ attól, milyen termékeket gyártanak majd az első vonalbeli rendszerintegrátorok, mennyire lesz széles a készülő modellek skálája, menynyire válik globálissá a verseny a második vonalban, mekkora lesz a különböző szinteken a koncentráció mértéke, mekkora lesz a piac nagysága. Mivel egy új modell kifejlesztése 2-3 év (Liker, 2008) - így a 2010ben piacra kerülő 160 új modell fejlesztését (Autonews, 2010b) még a válság előtt kezdték el -, a fenti kérdésekre nehéz lenne most választ adni.

Az alacsonyabb technológiai színvonalat képviselő (részben a hazai kisvállalkozások csoportjába tartozó, illetve részben a heterogén hazai középmezôny tagjai közül kikerüló) vállalatok előtt két út áll: proaktív stratégiával talán el lehet érni, hogy az elsố vonalbeli beszállítók részére fontos kiegészítő terméket gyártva, azokkal szorosan együttmúködve a vállalat, illetve annak terméke nehezebben váljon helyettesíthetôvé (ennek lehetôségei természetesen igen korlátozottak). Másik lehetôség a növekedés: az áralapú versenyben a méretgazdaságosság előnyeinek kihasználása a fellendülő környezetben ismét fontossá válhat. Erre viszont a válságban meggyengült, kevésbé tôkeerốs vállalatoknak kevés esélyük lehet.

Az ágazat növekvó koncentrációja, a mélyüló beszállitói kapcsolatok és a technológiai váltás miatt tehát kettészakadhat a jelenleg igen heterogén hazai vállalati kör, hiszen a hazai beszállitók többségének kapacitás- és technológiai korlátai a kialakuló új rendszerben nyilvánvalóvá válnak, míg a vállalatok egy része remélhetóleg sikeresen helyt tud állni a megváltozott környezetben is.

\section{Lábjegyzet}

'Bár a minta elemszáma viszonylag kicsi, ennek ellenére nem egyedülálló hasonló módszerek használata (lásd Csendes, 2004). A minta viszonylag kis elemszámának oka részben a teljes sokaság korlátozott nagysága. A Suzuki mintegy 60-70 első vonalbeli beszállítóval rendelkezik, a vertikális lánc rövid volta, a magas importhányad (lásd Mészáros, 2009) miatt azonban nehéz volt másodvonalbeli cégeket felkeresni. A kis mintanagyság másik oka a vállalatok elzárkózása.

${ }^{2}$ Az elnevezés Voszka Éva nagyvállalati átalakulást elemző műveiben olvasható metaforára utal (lásd például Voszka, 1997).

${ }^{3}$ Csak egy példa: 2010 elején, az autóipari recesszió közepén is növekedett a lítiumos akkumulátorok iránti kereslet, az amerikai autóipari beszállító, a Cellgard pedig új üzemet létesít ezek gyártására. Igaz, szerepe volt ebben a US Department of Energy által nyújtott 49 millió dolláros, technológiaváltást és munkahelyteremtést ösztönzó támogatásnak is (Autonews, 2010). A gazdaságpolitika támogatása a technológiai váltást jelentősen fel fogja gyorsítani.

\section{Felhasznált irodalom}

Aller et al. (1999): New Tendencies in Intern-firm Relations in the Automotive Industry and their Impact on European Periphery. Lessons from Spain. European Urban and Regional Studies Vol. 3, 255-264. old.

Árva L. (1997): Külföldi múködőtôke, hazai beszállítói kapcsolatok, külkereskedelmi mérleg és technológiatranszfer. Közgazdasági Szemle, XLIV. évf., 11. szám, 1007-1018. old.

Árva L. -Diczházy B. (1998): Globalizáció és külföldi tókeberuházások Magyarországon. Kairosz-Növekedéskutató, Budapest

Autonews (2010): Supplier Celgard building lithium-ion battery film plant in N.C. http://www.autonews.com/ apps/pbcs.dll/article?AID=/20100120/OEM05/100129 988/1128\#ixzz0dH9L20vg letöltés: 2010. január 21.

Autonews (2010b): Automotive news. http://www.autonews. com letöltés: 2010. február 1.

Bensaou, M. - Venkatraman, N (1995): Configurations of Interorganizational Relationships: A Comparison between U.S. and Japanese Automakers. Management Science, Vol. 41, No. 9 (Sept.) 1471-1492. old.

Csendes I. (2004): Internet-vállalkozások indításának stratégiai és motivációs elemzése - a magyar portálszolgáltató vállalatok esete. $\mathrm{PhD}$-értekezés, Budapest, BKÁE

Csonka L. (2009): Hálózatok az autóiparban: tanulás a kutatás-fejlesztés és az innováció érdekében. Külgazdaság, LIII. évf. július-augusztus, 89-109. old.

Deloitte (2009): Industry Outlook: Automotive. 28 January 2009. http://www.deloitte.com/view/en_US/us/Insights/hottopics/2009-Industry-Outlook/article/012d49642dff021 0VgnVCM100000ba42f00aRCRD.htm letöltés: 2009. november 20 .

Dyer, J.H. (1996): Specialized Supplier Networks as a Source of Competitive Advantage: Evidence from the 
Auto Industry. Strategic Management Journal, Vol. 17, No. 4 (Apr., 1996), 271-291. old.

Fujita, K. - Hill, R.C. (1995): Global Toyotaism and Local Development. International Journal of Urban and Regional Research Vol. 19, 7-22. old.

Futó P. - Hurton E. (1997): A kis- és középvállalkozások háttéripari-beszállítói együttmúködésének javítására, vállalkozói hálózatok kialakítására alkalmazható kormányzati technikák és ösztönzók, a fejlett országok tapasztalatainak figyelembevételével. Ipargazdasági $\mathrm{Ku}$ tató és Tanácsadó Kft., Budapest

Hamar J. (2001): A külföldi és a hazai tőkével múködő vállalatok szerepe a magyar iparban. Külgazdaság, 45. évf., 4. szám, 4-34. old.

Hamar J. - Nagy Á. (2001): A külföldi múködőtőke szerepe a magyar gazdaság fejlődésében, különös tekintettel néhány kiemelt ágazatra. Kopint-Datorg Rt., Budapest

Harvey, D. (2009b): Happier times ahead. AT Kearney. http:// www.atkearney.com/index.php/Publications/happiertimes-ahead-for-auto-suppliers.html?q=auto+suppliers letöltés: 2010. január 2.

Hirschman, A. O. (2000): Versengố nézetek a piaci társadalomról - és egyéb újabb keletû írások. Jószöveg Múhely Kiadó, Budapest

Hudson, R. (1994): New Production Concepts, New Production Geographies? Reflections on Changes in the Automobile Industry. Transactions of the Instittute of British Geographers, New Series, Vol. 19. No. 3. 331-345. old.

Humphrey, J. - Memedovic, O. (2003): The global automotive industry value chain: What prospects for upgrading by developing countries. Vienna: UNIDO http://www. unido.org/file-storage/download/?file\%5fid=11902 letöltés: 2008. március 9.

IMF (2009): World Economic Outlook. Crisis and Recovery. International Monetary Fund, Washington D.C.

Kim, J. - Michell, P. (1999): Relationship marketing in Japan: the buyer-supplier relationships of four automakers. Journal of Business and Industrial Marketing, Vol. 14, Issue 2. 118-130. old.

Liker, J. K. (2008): A Toyota-módszer. 14 Vállalatirányítási alapelv. HVG Kiadó, Budapest

Marchionne, S. (2008): This party is over. Automotive News Europe. www.autonews.com/article/20081208/ ANE03/812079963 letöltés: 2009. november 19.

Mészáros Á. (2004): A magyarországi közvetlen külföldi múködôtőke-beruházások exportenklávé jellege. Külgazdaság, 48. évf., 4. szám, 48-59. old.

Mészáros Á. (2009): A beszállítói lánc hossza és az importhányad. Egy autóipari kutatás eredményei. Fejlesztés és Finanszírozás, 4. szám, 26-35. old.

OECD (2009): The automobile industry in and beyond the crisis. Organization for Economic Cooperation and Development, http://www.oecd.org/ dataoecd/57/61/44089863.pdf letöltés: 2010. február 1 .
PWC (2009a): Drive value. Automotive Insights 2008. PricewaterhouseCoopers

http://www.pwc.com/en_GX/gx/automotive/pdf/ mergers-acquisitions-insights-2008.pdf letöltés: 2009. november 10 .

PWC (2009b): Capitalizing on change. Global Automotive Perspectives 2009. Issue 1.

http://www.pwc.com/en_GX/gx/automotive/pdf/ global-automotive-perspectives-2009-issue-1.pdf letöltés: 2009. november 1.

Sass M. - Szanyi M. (2004): A hazai cégek és a multinacionális vállalatok közötti beszállítói kapcsolatok alakulása. Külgazdaság, 48. évf. 9. szám, 4-23. old.

Sass M. - Czakó V. - Oszlay A. - Szanyi M. - Bakács A. (2006): A Beszállítói Programoktól a klasztertámogatásig. Nemzetközi tapasztalatok, hazai lehetőségek. Budapest: ICEG EC. http://icegec.hu/ hun/_docs/kutatasi_jelentesek/ICEG_EC_Beszallito_ klaszter_0929.pdf letöltés: 2008. november 28.

Somai M. (2009): Válság és autóipar. In: Szalavetz Andrea: A válság hatása néhány kiemelt gazdasági tevékenységre. MTA VKI. Budapest, 18-37. old.

Streeck, W. (1998): Book Review of Tolliday, Steven-Zeitlin, Jonatjan: The Automobile Industry and Its Workers: Between Fordism and Flexibility. The Business History Review. Vol. 62. No. 4. 720-722. old.

Suzuki (2009): A VW és a Suzuki átfogó együttmúködésbe kezd. Suzuki, 2009. december 9. http://www.suzuki. hu/pages/display/magyar_suzuki_zrt./cikk/cikk:a_vw_ es_a_suzuki_atfogo_egyuttmukodesbe_kezd_ letöltés 2009. december 30.

Turnbull, P. - Oliver, N. - Wilkinson, B. (1992): Buyersupplier relations in the UK automotive industry: strategic implications of the Japanese manufacturing model. Strategic Management Journal. Vol. 13. No. 2, 159-168. old.

UK Know How Fund (é.n.): Összefoglaló jelentés és javaslatok megfogalmazása a kkv-szektor lehetôségeinek fejlesztésére. Kézirat

UNCTAD (2001): World Investment Report 2001. Promoting Linkages. New York and Geneva: United Nations Conference on Trade and Development

US Department of Commerce (2009): U.S. Automotive Parts Industry Annual Assessment. April. http://www.trade. gov/wcm/groups/public/@trade/@mas/@man/@aai/ documents/web_content/auto_reports_parts2009.pdf letöltés: 2009. november 1.

Voszka É. (1997): A dinoszauruszok esélyei. Nagyvállalati átalakulás és privatizáció. Közgazdasági Szemle, január, 31-41. old.

Cikk beérkezett: 2010. 2. hó

Lektori vélemény alapján véglegesítve: 2010. 4. hó 